\title{
A Rare Cause of Carpal Tunnel Syndrome: Deep Tissue Lipomas
}

\author{
Karpal Tünel Sendromunun Nadir Nedenlerinden Biri: Derin Doku Lipomları
}

Selçuk Sayılır

Muğla Sıtkı Koçman University Faculty of Medicine, Department of Physical Medicine and Rehabilitation, Muğla, Turkey

\section{To the Editor}

A 44-year-old, right-handed female patient presented with a 3-year history of left hand numbness and pain in the median nerve distribution, admitted to our clinic. She did not report trauma to the wrist before symptom onset and there was not a family history of neurofibromatosis. Her pain was not responsive to any drugs. Electromyography and nerve conduction studies indicated left hand median nerve neuropathy at the wrist. Also, she did not report history of any constitutional symptoms. On the other hand, she did not have a history of endocrinological or rheumatological diseases in her family. On the physical examination; Tinel's sign was positive on the left hand. There was not significant atrophy of the thenar muscles in her hand and hypoalgesia, paresthesia in the lateral three and a half digits in the distribution of the median nerve were existed and external stigmatas of neurofibromatosis were absent. Magnetic resonance imaging (MRI) scans of the left forearm and hand showed a lipoma located near the flexor tendons beyond the transverse carpal ligament (Figure 1). Carpal tunnel syndrome (CTS) is a common neurological disorder which is associated with the compression of the median nerve at the wrist (1). Sensory or motor symptoms at the median nerve distrubition in the hand are the characteristics of the CTS. Pain, weakness of the hand muscles and paresthesia are common symptoms of the CTS (2). Although, the pathophysiology is still remains unclear, the main mechanism of the CTS is associated with compression of the median nerve (3). Deep soft-tissue lipomas are known as benign soft-tissue tumors and these tumors can be related to local compression of the adjacent peripheric nerves (4). These nerve compressions are exceptionally for median nerve (5). Although, CTS is a common disease and often appeared idiopatically, lipomas can cause median nerve compressions rarely. If the pathology can shown clearly, treatment would be more successful and surgeries can be more effective. The present patient was suggested for an operation for the lipoma associated CTS, but she did not accept the surgery and so,

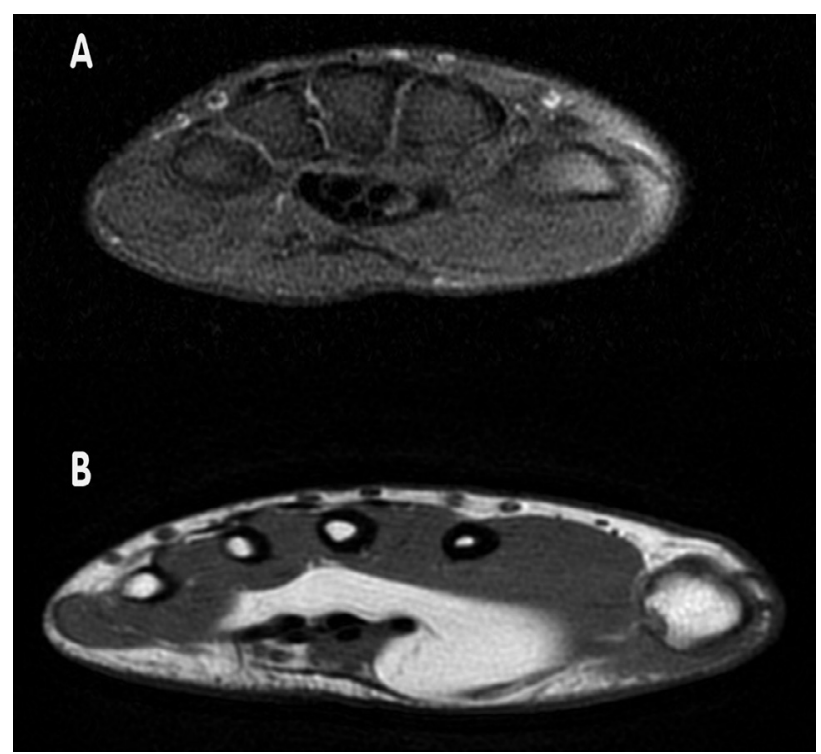

Figure 1. Magnetic resonance imaging investigations, A) magnetic resonance images of the patient shows thickening and oedema that is, a coaxial cable appearance on the axial view, B) magnetic resonance images of the patient show typical features of lipomas (1.5 Tesla magnetic resonance imaging, standard T1A spin-echo sequences, repetition time 300 ms, field of view $300 \mathrm{~mm}$, echo time, $25 \mathrm{~ms}$, slice thickness $4 \mathrm{~mm}$, number of signal averages, 4)

we could not have a certain classification for the lipoma due to pathological examination absence, this was a limitation. It should be pointed that patients whom have symptoms and signs of CTS (especially for a long time), can be related to the masses of the soft tissues. This situation can affect the treatment. If a lipoma exists and the clinician shows it clearly with imaging techniques (ultrasound/MRI), it will be helpful for the CTS operations and to prevent surgery surprises.

Keywords: Carpal tunnel syndrome, deep tissue lipomas, early diagnosis

Anahtar Kelimeler: Karpal tünel sendromu, derin doku lipomaları, erken tanı 


\section{Ethics}

Peer-review: Internally peer-reviewed.

\section{References}

1. Peters S, Page MJ, Coppieters MW, Ross M, Johnston V Rehabilitation following carpal tunnel release. Cochrane Database Syst Rev 2013;(6):CD004158.

2. Galasso O, Mariconda M, Donato G, Di Mizio G, Padua L, Brando $A$, et al. Histopathological, clinical, and electrophysiological features influencing postoperative outcomes in carpal tunnel syndrome. J Orthop Res 2011;29:1298-304.

3. Ettema AM, Amadio PC, Zhao C, Wold LE, An KN. A histological and immunohistochemical study of the subsynovial connective tissue in idiopathic carpal tunnel syndrome. J Bone Joint Surg Am 2004;86-A:1458-66.

4. Leffert RD. Lipomas of the upper extremity. J Bone Joint Surg Am 1972;54:1262-6.

5. Valbuena SE, O'Toole GA, Roulot E. Compression of the median nerve in the proximal forearm by a giant lipoma: A case report. J Brachial Plex Peripher Nerve Inj 2008;3:17. 